\title{
Fertilizer Prescriptions for Rice Based on STCR -IPNS
}

\author{
U. Bagavathi Ammal ${ }^{1 *}$, R. Sankar ${ }^{1}$, K. Coumaravel ${ }^{1 *}$ and Pradip Dey ${ }^{2}$ \\ ${ }^{1}$ Department of Soil Science and Agricultural Chemistry, Pandit Jawaharlal Nehru College of \\ Agriculture and Research Institute, Karaikal-609603, India \\ ${ }^{2}$ Project Coordinator, Indian Institute of Soil Science, Bhopal-462 038, India \\ *Corresponding author
}

\section{Keywords \\ Fertilizer prescription equation, Nutrient requirement, Rice yield and yield target}

Article Info

Accepted:

20 September 2020 Available Online: 10 October 2020

\section{A B S T R A C T}

To develop fertilizer prescription equation for rice, a field experiment was conducted on an inceptisol of farmer's field at Arachikuppam village, Puducherry during 2015 by using integrated plant nutrient management system on the basis of STCR approach. The rice grain and straw yield was significantly increased with the soil test values and fertilizer doses of $\mathrm{N}, \mathrm{P}$ and $\mathrm{K}$. Based on the experiment, the nutrient requirement for producing 1 quintal of rice grain was $1.46 \mathrm{~kg}$ of $\mathrm{N}, 0.60$ $\mathrm{kg}$ of $\mathrm{P}_{2} \mathrm{O}_{5}$ and $1.12 \mathrm{~kg}$ of $\mathrm{K}_{2} \mathrm{O}$, respectively. The percent nutrient contribution from soil was 20.18, 21.39 and 19.52, from fertilizer 39.04, 39.39 and 70.97 and from organic manure 23.06, 30.40 and 55.03 for $\mathrm{N}, \mathrm{P}_{2} \mathrm{O}_{5}$ and $\mathrm{K}_{2} \mathrm{O}$ respectively. By using the basic parameters the soil test based fertilizer adjustment equations for specific targets of rice grain yield of 7.0 and $8.0 \mathrm{t} \mathrm{ha}^{-1}$ have been calibrated based on the targeted yield concept. These fertilizer prescription equations developed for Rice (var.) White Ponni can be used to estimate fertilizer doses formulated for the range of soil test values and desired yield targets under NPK alone and IPNS ( NPK plus FYM).

\section{Introduction}

Rice (Oryza sativa L.) is central to the lives of billions of people around the world. At the global level, rice is the most widely grown crop which occupies an area of about 161.8 million hectares, of which Asia covers about 143.2 million hectares. Similarly, Out of the total world rice production of 701 million tons, Asia contributes approximately 633.7 million tons (FAO Statistical year book, 2013). The slogan 'Rice is life' is most appropriate for India; as this crop plays a vital role in our India's food security and is a mean of livelihood for millions of rural households (Ajaykumar et al., 2016). In India, more than 44 million hectares area is occupied by rice under three major ecosystems, rainfed uplands (16\% area), irrigated medium lands $(45 \%)$ and rainfed lowland (39\%), with a 
productivity of $0.87,2.24$ and 1.55 tons per hectare, respectively (Tiwari et al., 2013). The rice production largely depends upon the resource availability, varietal potential and nutrient management technologies. The nutrient management is one of the most important input in agriculture.

The annual consumption of fertilizers, in nutrient forms ( $\mathrm{N}, \mathrm{P}$ and $\mathrm{K}$ ) has increased from 0.07 million tons in 1951-52 to more than 28 million tons in 2010-11 and per hectare consumption has increased from less than $1 \mathrm{~kg}$ in $1951-52$ to the level of $135 \mathrm{~kg}$ in 2010-11 (Karsangla and Gohain, 2015), the nutrient use efficiency has gone down from $16 \mathrm{~kg}$ food grain produced per $\mathrm{kg}$ NPK applied during 1970's to $8 \mathrm{~kg}$ food grain produced per kg NPK applied during 1990's and around $6 \mathrm{~kg}$ now due to increasing deficiency of secondary and micronutrient (Tiwari et al., 2013). The blanket fertilizer recommendation are based on crop responses without taking into account the spatial and temporal variability of the soils and the results is over / under use entailing economic / yield losses. Therefore, it is necessary to supplement crops with organic and inorganic fertilizers sources in order to maintain the nutrient supply and also to correct the deficiency of secondary and micronutrients. This can be offset only by adopting soil testing and applying integrated plant nutrient supply as has been enunciated as " The Law of Optimum", which has been demonstrated and validated in numerous farmer's field for obtaining targeted yield of crops under the All India Co-ordinated Research Project on Soil Test Crop Response (AICRP-STCR) project annual reports (Ramamoorthy and Velayutham, 2011, Tandan 2014 and Velayutham et al., 2016).

The targeted yield approach wherein Ramamoorthy et al., (1967) established the theoretical basis and experimental proof for the fact that Liebig's law of minimum operates equally well for N, P and K. Among the various methods of fertilizer recommendation, the one based on yield targeting is unique in the sense that this method not only indicates soil test based fertilizer doses but also the level of yield the farmer can hope to achieve if good agronomic practices are followed in raising the crop. Targeted yield concepts strikes a balance between "Fertilizing the crop" and "Fertilizing the soil". The objective of this study was to develop the fertilizer prescriptions for rice crop in alluvial soil (Inceptisols) at different soil fertility levels under the conditions of fertilizer scarcity and to ensure maximum fertilizer use efficiency. The study also intended to find the relationship between nutrients supplied by the soil and added by organic and inorganic sources, their uptake and to develop a guideline for judicious application of fertilizer for desired yield target of rice by using STCR model.

\section{Materials and Methods}

A field experiment was conducted with rice as test crop during 2015 on alluvial soil (Inceptisol) of farmer's field at Arachikuppam village, Puducherry to develop targeted yield equation following the procedure of Ramamoorthy et al., (1967). The field was divided into three strips of equal size and in each strip, The first strip received no fertilizer $\left(\mathrm{N}_{0} \mathrm{P}_{0} \mathrm{~K}_{0}\right)$, the second and third received one $\left(\mathrm{N}_{1} \mathrm{P}_{1} \mathrm{~K}_{1}\right)$ and two $\left(\mathrm{N}_{2} \mathrm{P}_{2} \mathrm{~K}_{2}\right)$ times the standard dose of $\mathrm{N}, \mathrm{P}_{2} \mathrm{O}_{5}$ and $\mathrm{K}_{2} \mathrm{O}$ respectively were applied to develop a fertility gradient, and rice variety ADT 39 was grown as an exhaust crop during summer 2015 for stabilizing fertility gradient in the field. Crop was harvested at maturity. In the succeeding season, rice variety White Ponni was grown as test crop during rabi (2015) in the same field in which fertility gradient stabilizing experiment was 
conducted. Each strip made (made in the fertility gradient stabilizing experiment in the previous season) was divided into 24 (21 treated and 3 control plots equal sized $(4 \mathrm{~m} \mathrm{x}$ $4 \mathrm{~m})$ plots resulting in total of $72(24 \mathrm{x} 3)$ plots. Three blocks $(\mathrm{A}, \mathrm{B}, \mathrm{C})$ comprising of 8 treatments were made within each strip randomized with farmyard manure (FYM) levels. The various levels of FYM (0.6.25 and $\left.12.5 \mathrm{t} \mathrm{ha}^{-1}\right)$ and fertilizer [four levels of $\mathrm{N}(0$, 50,100 and $150 \mathrm{~kg} \mathrm{ha}^{-1}$ ), four levels of $\mathrm{P}_{2} \mathrm{O}_{5}$ $\left(0,25,50\right.$ and $\left.75 \mathrm{~kg} \mathrm{ha}^{-1}\right)$ and four levels of $\mathrm{K}_{2} \mathrm{O}\left(0,25,50\right.$ and $\left.\left.75 \mathrm{~kg} \mathrm{ha}^{-1}\right)\right]$ were used. Treatments of $\mathrm{N}, \mathrm{P}_{2} \mathrm{O}_{5}, \mathrm{~K}_{2} \mathrm{O}$ and FYM were used as shown in Table 1. Fertilizer used was urea, Single Super Phosphate (SSP) and Muriate of Potash (MOP). Full dose of $\mathrm{P}_{2} \mathrm{O}_{5}$ and $\mathrm{K}_{2} \mathrm{O}$ were applied as basal were $\mathrm{N}$ was applied in three equal splits, half as basal and remaining tillering, panicle initiation and flowering stages.

Plot-wise nutrient levels were tested before applying FYM and NPK. Soil samples (0$15 \mathrm{~cm}$ ) from all the 72 plots were collected and analyzed for available $\mathrm{N}$ by the alkaline permanganate method (Subbiah and Asija 1956); available $\mathrm{P}$ by $0.5 \mathrm{MNaHCO}_{3}$ (Olsen et $a l ., 1954)$ and available $\mathrm{K}$ by the ammonium acetate method (Stanford and English 1949) as described by Jackson (1973).

Rice grain and straw yield were recorded separately at maturity and plant samples were taken for estimation of $\mathrm{N}, \mathrm{P}$ and $\mathrm{K}$ contents for working out uptake by the crop. Plot-wise soil test data, fertilizer doses, yield and uptake were used for obtaining NR (nutrient required to produce one tone of rice grain), \%CS (per cent contribution of nutrients from soil) $\% \mathrm{CF}$ (per cent contribution of nutrients from fertilizers) and \% Cfym (per cent contribution of nutrients from organic matter), as per method described by Ramamoorthy et al., (1967).
These parameters were used to develop equations for soil test based fertilizer recommendations for desired yield targets of rice under NPK alone as well as NPK plus FYM.

\section{Results and Discussion}

\section{Soil available nutrients and grain yield}

The range and mean values of soil available nutrients and grain yield of rice in treated and control plots are furnished in table 2 . In the NPK treated plots (Plots that received NPK alone or NPK plus FYM) $\mathrm{KMnO}_{4}-\mathrm{N}$ increased from $159.6 \mathrm{kgha}^{-1}$ in strip 1 to 271.6 $\mathrm{kgha}^{-1}$ in strip III with a mean value of $210.0 \mathrm{kgha}^{-1}$. The Olsen-p ranged from 19.2 to $36.8 \mathrm{~kg} \mathrm{P}_{2} \mathrm{O}_{5} \mathrm{ha}^{-1}$, while the $\mathrm{NH}_{4} \mathrm{OAc}-\mathrm{K}$ status varied from 107 to $161 \mathrm{kgK}_{2} \mathrm{Oha}^{-1}$

In the NPK treated plots that received NPK alone or NPK plus FYM, the yield of rice ranged from 3570 to $8010 \mathrm{kgha}^{-1}$ with a mean value $5720 \mathrm{kgha}^{-1}$. In the overall control plot, the yield ranged from 2750 to $3250 \mathrm{kgha}^{-1}$ with a mean value of $2983 \mathrm{kgha}^{-1}$.

In the overall control plot of three fertility gradients (Table 2), the $\mathrm{KMnO}_{4}-\mathrm{N}$ ranged from 176.4 to $193.2 \mathrm{kgha}^{-1}$ with a mean of $168.0 \mathrm{~kg} \mathrm{ha}^{-1}$, Olsen-P status ranged from 33.1 to $35.6 \mathrm{kgha}^{-1}$ with a mean value of 28.0 $\mathrm{kgha}^{-1}$ and the $\mathrm{NH}_{4} \mathrm{OAc}-\mathrm{K}$ status varied from 141 to $162 \mathrm{~kg} \mathrm{~K}_{2} \mathrm{O} \mathrm{ha}^{-1}$ with a mean value of $114 \mathrm{~kg} \mathrm{~K} \mathrm{~K}_{2} \mathrm{O} \mathrm{ha}^{-1}$. Though these soils are considered as fertile, they are low in $\mathrm{N}$ and high in $\mathrm{P}$ and medium in $\mathrm{K}$.

The above data clearly indicate the existence of operational range of soil test values for available $\mathrm{N}, \mathrm{P}$ and $\mathrm{K}$ status and yield of treated and control plots, which is prerequisite for calculating the basic parameters and fertilizer prescription equations for calibrating the fertilizer doses for specific yield targets. 
The equations are

$$
\begin{aligned}
& \text { NPK Alone } \\
& \mathrm{FN}=3.75 \mathrm{~T}-0.52 \mathrm{SN} \\
& \mathrm{FP}_{2} \mathrm{O}_{5}=1.53 \mathrm{~T}-1.24 \mathrm{SP} \\
& \mathrm{FK}_{2} \mathrm{O}=1.58 \mathrm{~T}-0.33 \mathrm{SK} \\
& \mathrm{NPK}+\text { FYM } \\
& \mathrm{FN}=3.75 \mathrm{~T}-0.52 \mathrm{SN}-0.59 \mathrm{ON} \\
& \mathrm{FP}_{2} \mathrm{O}_{5}=1.53 \mathrm{~T}-1.24 \mathrm{SP}-1.77 \mathrm{OP} \\
& \mathrm{FK}_{2} \mathrm{O}=1.58 \mathrm{~T}-0.33 \mathrm{SK}-0.93 \mathrm{OK} \\
& \mathrm{FN}=\text { Fertilizer } \mathrm{N}\left(\mathrm{kg} \mathrm{ha}^{-1} .\right) \\
& \mathrm{FP}=\mathrm{Fertilizer} \mathrm{P}_{2} \mathrm{O}_{5}\left(\mathrm{~kg} \mathrm{ha}^{-1} .\right) \\
& \mathrm{Fk}=\text { Fertilizer } \mathrm{K}_{2} \mathrm{O}\left(\mathrm{kg} \mathrm{ha}^{-1} .\right) \\
& \mathrm{T}=\text { yield target }\left(\mathrm{qha}^{-1}\right)
\end{aligned}
$$

Where, SN, SP, SK, respectively are alkaline $\mathrm{KMnO}_{4}-\mathrm{N}$, Olsen-P and $\mathrm{NH}_{4} \mathrm{OAc}-\mathrm{K}$ in $\mathrm{kg}$ $\mathrm{ha}^{-1}$ of soil and ON, OP and OK are the quantities of $\mathrm{N}, \mathrm{P}$ and $\mathrm{K}$ in $\mathrm{kg} \mathrm{ha}^{-1}$ supplied through FYM respectively.

\section{Basic parameters}

The basic data viz., nutrient requirement for producing one quintal grain of Rice, per cent contribution of nutrients from soil(\%CS),
fertilizer(\%CF) and FYM(\%Cfym) have been calculated (Table 3). These basic parameters were used for developing fertilizer prescription equations under NPK alone and NPK plus FYM. The nutrient requirement of $\mathrm{N}, \mathrm{P}_{2} \mathrm{O}_{5}$ and $\mathrm{K}_{2} \mathrm{O}$ were $1.46,0.60$ and $1.12 \mathrm{~kg}$ $\mathrm{q}^{-1}$ of grain, respectively. The \%CS and \%CF were found to be 20.18 and 39.04 for N, 21.39 and 39.39 for $\mathrm{P}_{2} \mathrm{O}_{5}$ and 19.52 and 70.97 for $\mathrm{K}_{2} \mathrm{O}$. Similarly, the percent contribution of $\mathrm{N}$, $\mathrm{P}_{2} \mathrm{O}_{5}$ and $\mathrm{K}_{2} \mathrm{O}$ from FYM was 23.06, 30.04 and 55.03, respectively. It was noted that contribution from fertilizer for rice was higher in comparison to soil. The high value of potassium could be due to the interaction effect of higher doses of $\mathrm{N}, \mathrm{P}$ coupled with priming effect of $\mathrm{K}$ doses in the treated plots, which might have caused the release of soil potassium, resulting in higher uptake from the native soil sources by the crop (Ray et al., 2000). Similar type of higher efficiency of potassic fertilizers was also reported for rice by Ahmed and Reddy (2002) in alluvial soils. Among the three nutrients, the per cent contribution from soil was higher for $\mathrm{P}_{2} \mathrm{O}_{5}$ followed by $\mathrm{N}$ and $\mathrm{K}_{2} \mathrm{O}$. Similar trend of contribution of nutrients from soil to the total uptake was reported by Natesan et al., (2007) for different rice varieties.

Table.1 Levels of Nitrogen, Phosphorous, potassium and FYM used in the experiment

\begin{tabular}{|l|c|c|c|}
\hline $\mathbf{N}\left(\mathbf{k g ~ h a}^{\mathbf{- 1}}\right)$ & $\mathbf{P}_{\mathbf{2}} \mathbf{O}_{\mathbf{5}}\left(\mathbf{k g ~ h a}^{\mathbf{- 1}}\right)$ & $\mathbf{K}_{\mathbf{2}} \mathbf{O}\left(\mathbf{k g ~ h a}^{\mathbf{- 1}}\right)$ & $\mathbf{F Y M}\left(\mathbf{t} \mathbf{~ h a}^{\mathbf{- 1}}\right)$ \\
\hline $\mathbf{0}$ & 0 & 0 & 0 \\
\hline $\mathbf{5 0}$ & 25 & 25 & 6.25 \\
\hline $\mathbf{1 0 0}$ & 50 & 50 & 12.5 \\
\hline $\mathbf{1 5 0}$ & 70 & 70 & - \\
\hline
\end{tabular}

Table.2 Available nutrients in pre-sowing surface soil and yield of rice crop

\begin{tabular}{|l|c|c|c|c|}
\hline \multirow{2}{*}{ Parameters } & \multicolumn{2}{|c|}{ NPK treated plots } & \multicolumn{2}{c|}{ Control plots } \\
\cline { 2 - 5 } & Range & Mean & Range & Mean \\
\hline KMnO$_{\mathbf{4}}-\mathbf{N}\left(\mathbf{k g h a}^{-\mathbf{1}}\right)$ & $159.6-271.6$ & 210.0 & $176.4-193.2$ & 168.0 \\
\hline Olsen-P $\left(\mathbf{k g h a}^{-\mathbf{1}}\right)$ & $19.2-36.8$ & 28.6 & $33.1-35.6$ & 28.0 \\
\hline $\mathbf{N H}_{\mathbf{4}} \mathbf{O} \mathbf{O c}-\mathrm{K}\left(\mathbf{k g h a}^{-\mathbf{1}}\right)$ & $107-161$ & 130 & $141-162$ & 114 \\
\hline Yield $\left(\mathbf{k g ~ h a}^{-\mathbf{1}}\right)$ & $3570-8010$ & 5720 & $2750-3250$ & 2983 \\
\hline
\end{tabular}


Table.3 Basic data for fertilizer adjustment of Rice

\begin{tabular}{|c|c|c|c|}
\hline Basic data & $\mathbf{N}$ & $\mathbf{P}_{2} \mathrm{O}_{5}$ & $\mathbf{K}_{2} \mathbf{O}$ \\
\hline Nutrient requirement $\left(\mathrm{Kg} \mathrm{q}^{-1}\right)$ & 1.46 & 0.60 & 1.12 \\
\hline Soil efficiency $(\%)$ or \% CS & 20.18 & 21.39 & 19.52 \\
\hline Fertilizer efficiency $(\%)$ or $\% \mathrm{CF}$ & 39.04 & 39.39 & 70.97 \\
\hline $\begin{array}{c}\text { Organic efficiency }(\%) \text { or } \\
\text { \% Cfym }\end{array}$ & 23.06 & 30.40 & 55.03 \\
\hline
\end{tabular}

Table.4 Estimation of soil test based fertilizer recommendation for $7.0 \mathrm{t}^{-1}$ ha grain yield target of Rice crop

\begin{tabular}{|c|c|c|c|c|c|c|c|c|}
\hline \multicolumn{3}{|c|}{$\begin{array}{l}\text { Soil Test values } \\
\quad\left(\mathrm{kg} \mathrm{ha}^{-1}\right)\end{array}$} & \multicolumn{3}{|c|}{$\begin{array}{c}\text { Fertilizer Doses }\left(\mathrm{kg} \mathrm{ha}^{-1}\right) \text { under } \\
\text { NPK alone }\end{array}$} & \multicolumn{3}{|c|}{$\begin{array}{c}\text { Fertilizer doses }\left(\mathrm{kg} \mathrm{ha}^{-1}\right) \\
\text { under NPK + FYM@ } 12.5 \\
\text { ha }^{-1}\end{array}$} \\
\hline SN & $\mathrm{SP}_{2} \mathrm{O}_{5}$ & $\mathrm{SK}_{2} \mathrm{O}$ & $\mathrm{FN}$ & $\mathrm{FP}_{2} \mathrm{O}_{5}$ & $\mathrm{FK}_{2} \mathrm{O}$ & FN & $\mathrm{FP}_{2} \mathrm{O}_{5}$ & $\mathrm{FK}_{2} \mathrm{O}$ \\
\hline 160 & 10 & 100 & 180 & 95 & 77 & 134 & 69 & 42 \\
\hline 200 & 12 & 120 & 159 & 92 & 71 & 113 & 66 & 36 \\
\hline 240 & 14 & 140 & 139 & 90 & 64 & 93 & 64 & 29 \\
\hline 280 & 16 & 160 & 118 & 87 & 57 & 75 & 61 & 25 \\
\hline 320 & 18 & 180 & 100 & 85 & 51 & 60 & 59 & 25 \\
\hline
\end{tabular}

An estimate of fertilizer doses was prepared based on these equations for a range of soil test values and for yield target of 7.0 tha $^{-1}$ of rice (Table 4). For achieving this target with the soil test values of $200: 12: 120 \mathrm{~kg} \mathrm{ha}^{-1}$ of $\mathrm{KMnO}_{4}-\mathrm{N}$, Olsen-P and $\mathrm{NH}_{4} \mathrm{O}$ Ac- $\mathrm{K}$, the fertilizer $\mathrm{N}, \mathrm{P}_{2} \mathrm{O}_{5}$ and $\mathrm{K}_{2} \mathrm{O}$ doses required were 159,92 and $71 \mathrm{~kg} \mathrm{ha}^{-1}$, respectively, where FYM $(0.51,0.29$ and $0.39 \%$ of N,P and $\mathrm{K}$, respectively) was applied @ $12.5 \mathrm{t} \mathrm{ha}^{-1}$ along with NPK, the required fertilizer $\mathrm{N}, \mathrm{P}_{2} \mathrm{O}_{5}$ and $\mathrm{K}_{2} \mathrm{O}$ doses were 113, 66 and 36 $\mathrm{kg} \mathrm{ha}^{-1}$, respectively. Under IPNS system the required dose of fertilizer is low due to nutrient availability increased by FYM through mineralization. Singh et al., (2015) also reported that under irrigated plant nutrient system, required dose of fertilizer to achieve desired yield target are reduced.

In conclusions, use of integrated plant nutrient management system resulted in saving of fertilizer nutrients in rice crop. Target yield equations generated from STCR-IPNS technology ensures not only sustainable crop production but also economic use of costly fertilizer inputs. Generally, soil productivity and health may be more sustainable with the integrated application of FYM and inorganic fertilizers than with the use of inorganic fertilizer alone.

\section{Acknowledgment}

The financial assistance of AICRIP-STCR, Bhopal to carry out the research is gratefully acknowledged.

\section{References}

Ahmed, S.R. and P.V.K. Reddy. 2002. Optimizing fertilizer doses for rice in alluvial soils through chemical fertilizers, farm yard manure and green manure using soil test values. Agropedology, 12: 133-140. 
Ajaykumar. R., R. Venkitaswamy and A. Rajeshkumar. 2016. Sustainable nutrient management practices to increase the productivity of transplanted low land rice. Cleanup India, 13-15 Dec. 2016, TNAU, Coimbatore.

FAO Statistical Yearbook. 2013. World food and agriculture. Food and Agriculture Organization of the United Nations, Rome.

Jackson, M.L. 1973. Soil chemical analysis. Prentice Hall of India Private Ltd., New Delhi.

Karsangla, A.O. and T. Gohain. 2015. Effect of different doses of NPK fertilizers on local rice (Oryza sativa L.) under directseeded upland condtion. J. Soils and Crops, 25(1): 54-61.

Natesan, R., P. Murugesa Boopathi, R. Santhi, S. Thiyageswari, N. Chandra Sekaran, C. Paulraj, S. Natarajan, A. Subba Rao and Y. Muralidharudu. 2007. Bull. Soil Test Crop Response based fertilizer prescription for different soils and crops in Tamil Nadu.

Olsen, S.R., Cole. C.V., Watanabe. F.S. and Dean. L.A. 1954. Estimation of available phosphorus in soil by extraction with sodium bicarbonate. USDA, CIRC. 939.

Ramamoorthy, B and M. Velayutham. 2011. The Law of Optimum and soil test base fertilizer use for targeted yield of crops and soil fertility management for sustainable agriculture. Madras Agric. J., 98(10-12): 295-307.

Ramamoorthy, B., R.K. Narasimham and R.S.
Dinesh. 1967. Fertilizer application for specific yield targets on Sonora 64 (wheat). Indian FMG., 17: 43-45.

Ray, P., K. Jana, A.K. Maitra, D.N. Saha, M.N. Chaudhury, J.S. Saha and A.R. Saha. 2000. Fertilizer prescription on soil test basis for jute, rice and wheat in a Typic Ustochrept. J. Indian Soc. Soil Sci.,48: 79-84.

Singh, Y.V., M. Parihar, S.K. Singh, P.K. Sharma and Pradipdey. 2015. Soil test based fertilizer prescriptions under integrated plant nutrient management system for maize in an Inceptisol of Varanasi. J. Indian Soc. Soil Sci., 63: 83-87.

Stanford, Soil and Leg English. 1949. Use of flame photometer on rapid sol tests of K. Canadian J. Agron., 41: 446-447.

Subbiah. S.V. and Asija. C.L. 1956. A rapid procedure for the estimation of available nitrogen in soil. Curr. Sci., 25: 259-260.

Tandon, HLS. 2014. Soil testing for balanced fertilization. FDCO, New Delhi.p.170.

Tiwari, R.K., A. Jha, S.K. Tripathi, I.M. Khan and S.K. Rao. 2013. Rice based cropping system and climate change. JNKVV. Res. J., 47: 239-247.

Velayutham, M. M., Santhi,R., Subba Rao, A., Muralidharudu, Y. and Dey,P.2016. The Law of Optimum and its application for realizing Targeted yields in India- A mini- review (Thaninayagam Adigal), March 2016. P.12-20.

\section{How to cite this article:}

Bagavathi Ammal, U., R. Sankar, K. Coumaravel and Pradip Dey. 2020. Fertilizer Prescriptions for Rice Based on STCR -IPNS. Int.J.Curr.Microbiol.App.Sci. 9(10): 2517-2522. doi: https://doi.org/10.20546/ijcmas.2020.910.302 